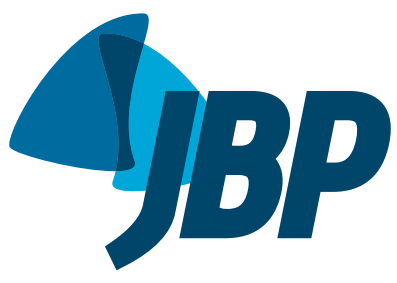

1. Departamento de Cardiopneumologia, Disciplina de Cirurgia Torácica, Instituto do Coração, Hospital das Clínicas, Faculdade de Medicina, Universidade de São Paulo, São Paulo (SP) Brasil.

2. Serviço de Cirurgia Torácica, Hospital Geral de Caxias do Sul, Fundação Universidade de Caxias do Sul (RS) Brasil.

3. Serviço de Cirurgia Torácica, Pavilhão Pereira Filho, Complexo Hospitalar da Santa Casa de Porto Alegre, Porto Alegre (RS) Brasil.

4. Hospital Monte Klinikum, Fortaleza (CE) Brasil.

5. Hospital de Messejana Doutor Carlos Alberto Studart Gomes, Fortaleza (CE) Brasil.

6. Casa de Saúde São José, Rio de Janeiro (RJ) Brasil.

7. Universidade Federal do Rio Grande do Norte, Natal (RN) Brasil.

8. Hospital Professor Edmundo Vasconcelos, São Paulo (SP) Brasil.

9. Hospital do Servidor Público Estadual de São Paulo, São Paulo (SP) Brasil.

10. Hospital de Base do Distrito Federal, Brasília (DF) Brasil.

11. Hospital Samaritano, Rio de Janeiro (RJ) Brasil.

12. Serviço de Cirurgia Torácica, Hospital de Clínicas de Porto Alegre, Faculdade de Medicina, Universidade Federal do Rio Grande do Sul, Porto Alegre (RS) Brasil.

13. Hospital Geral César Cals, Fortaleza (CE) Brasil.

14. Instituto Mário Penna, Hospital Luxemburgo, Belo Horizonte (MG) Brasil.

15. Hospital Naval Marcílio Dias, Rio de Janeiro (RJ) Brasil.

Submitted: 16 December 2015

Accepted: 6 April 2016.

Study carried out in the Departamento de Cardiopneumologia, Disciplina de Cirurgia Torácica, Instituto do Coração, Hospital das Clínicas, Faculdade de Medicina, Universidade de São Paulo, and Sociedade Brasileira de Cirurgia Torácica, São Paulo (SP) Brasil.

\section{Anatomic pulmonary resection by video- assisted thoracoscopy: the Brazilian experience (VATS Brazil study)}

Ricardo Mingarini Terra', Thamara Kazantzis'1, Darcy Ribeiro Pinto-Filho², Spencer Marcantonio Camargo ${ }^{3}$, Francisco Martins-Neto ${ }^{4,5}$, Anderson Nassar Guimarães ${ }^{6}$, Carlos Alberto Araújo 7 , Luis Carlos Losso ${ }^{8}$, Mario Claudio Ghefter ${ }^{9}$, Nuno Ferreira de Lima ${ }^{10}$, Antero Gomes-Neto ${ }^{5}$, Flávio Brito-Filho ${ }^{10}$, Rui Haddad ${ }^{11}$, Maurício Guidi Saueressig ${ }^{12}$, Alexandre Marcelo Rodrigues Lima $^{13}$, Rafael Pontes de Siqueira ${ }^{5}$, Astunaldo Júnior de Macedo e Pinho ${ }^{14}$, Fernando Vannucci ${ }^{15}$

\section{ABSTRACT}

Objective: The objective of this study was to describe the results of anatomic pulmonary resections performed by video-assisted thoracoscopy in Brazil. Methods: Thoracic surgeons (members of the Brazilian Society of Thoracic Surgery) were invited, via e-mail, to participate in the study. Eighteen surgeons participated in the project by providing us with retrospective databases containing information related to anatomic pulmonary resections performed by video-assisted thoracoscopy. Demographic, surgical, and postoperative data were collected with a standardized instrument, after which they were compiled and analyzed. Results: The surgeons provided data related to a collective total of 786 patients (mean number of resections per surgeon, 43.6). However, 137 patients were excluded because some data were missing. Therefore, the study sample comprised 649 patients. The mean age of the patients was 61.7 years. Of the 649 patients, 295 (45.5\%) were male. The majority—521 (89.8\%)—had undergone surgery for neoplasia, which was most often classified as stage IA. The median duration of pleural drainage was 3 days, and the median hospital stay was 4 days. Of the 649 procedures evaluated, $598(91.2 \%)$ were lobectomies. Conversion to thoracotomy was necessary in 30 cases (4.6\%). Postoperative complications occurred in 124 patients $(19.1 \%)$, the most common complications being pneumonia, prolonged air leaks, and atelectasis. The 30 -day mortality rate was $2.0 \%$, advanced age and diabetes being found to be predictors of mortality. Conclusions: Our analysis of this representative sample of patients undergoing pulmonary resection by video-assisted thoracoscopy in Brazil showed that the procedure is practicable and safe, as well as being comparable to those performed in other countries.

Keywords: Thoracic surgery, video-assisted; Thoracoscopy; Pneumonectomy.

\section{INTRODUCTION}

In the last 20 years, the development of minimally invasive surgery has evolved constantly. This technique minimizes trauma response and optimizes patient recovery without compromising surgical results. ${ }^{(1-5)}$ Thoracic surgery has followed this same path, which means that anatomic pulmonary resections by video-assisted thoracoscopy are routinely performed in hospitals around the world, and the number of studies that report increasingly complex surgeries, such as video-assisted thoracoscopic lobectomy with bronchoplasty for the treatment of hilar lymph node enlargement and large tumors, has increased in recent years. ${ }^{(6-11)}$

Despite the proven advantages of the minimally invasive approach, technical and financial limitations make its implementation difficult, especially in developing countries, such as India, Mexico, and Brazil. Therefore, to date, we do not yet have data from studies conducted in Brazil that can confirm the applicability and safety of the technique in our country, taking into account the particular characteristics of the patients and centers that provide care to them. (1,2,4,12) $^{(2)}$

The primary objective of the present study was to analyze the results of anatomic pulmonary resections performed by video-assisted thoracoscopy in Brazil, including

Correspondence to:

Ricardo Mingarini Terra. Avenida Dr. Enéas de Carvalho Aguiar, 44, Bloco II, $2^{\circ}$ Andar, Sala 9, CEP 05403-900, São Paulo, SP, Brasil.

Tel.: 5511 2661-5000. E-mail: rmterra@uol.com.br

Financial support: None. 
intraoperative complications, postoperative complications, and 30-day mortality. As a secondary objective, we sought to determine predictors of postoperative complications and 30-day mortality in our current scenario.

\section{METHODS}

This was a retrospective study commissioned by the Sociedade Brasileira de Cirurgia Torácica (SBCT, Brazilian Society of Thoracic Surgery), including data provided by 14 thoracic surgery groups in Brazil. The participating groups volunteered to donate data to the present study after an invitation was sent via e-mail to all members of the SBCT. To participate, interested parties should provide data related to anatomic pulmonary resections performed by video-assisted thoracoscopy. The minimum number of cases required for a group to be eligible for participation was 20 complete cases. The study project was approved by the Research Ethics Committee of the University of São Paulo School of Medicine (CAAE no. 40434414.6.0000.0065).

Cases of patients who underwent anatomic pulmonary resection by video-assisted thoracoscopy were included. Anatomic resections are those in which dissection and ligation is carried out regardless of the hilar structures, consisting of segmentectomy, lobectomy, or pneumonectomy. Video-assisted thoracoscopic procedures were defined as those in which there was no intercostal separation and incisions were $<8 \mathrm{~cm}$. ${ }^{(13)}$ Cases in which data on preoperative comorbidities, length of hospital stay, and postoperative complications were missing were excluded. The absence of only one of these data sets was not considered to be an exclusion criterion.

After accepting the invitation from the SBCT, the interested parties contacted the corresponding author and received a standardized instrument for data collection. The instrument contained closed-ended response fields and definitions for each variable.

The variables collected consisted of patient demographics (age, gender, diagnosis, and comorbidities), surgery-related data (date, type of procedure, and intraoperative complications), and surgical results (duration of drainage, length of hospital stay, and morbidity). Below are the definitions used for the various postoperative variables collected ${ }^{(14-17)}$ :

\section{Respiratory complications}

- Pneumonia: presence of persistent or progressive pulmonary infiltrates on chest X-ray and at least two of the following clinical criteria: temperature $\geq$ $38^{\circ} \mathrm{C}$; leukocytosis $>12,000$ cells/ $\mu \mathrm{L}$ or leukopenia $<3,000$ cells/ $\mu \mathrm{L}$; or purulent tracheal secretions with $\geq 25$ neutrophils and $\leq 10$ squamous epithelial cells per field (magnification, $\times 100$ )

- Pulmonary thromboembolism diagnosed by CT angiography

- Atelectasis requiring bronchoscopic intervention
- Respiratory failure: prolonged intubation (> 48 $\mathrm{h}$ or need for orotracheal reintubation in the postoperative period)

- ARDS: hypoxemia and diffuse pulmonary infiltrates with a $\mathrm{PaO}_{2} / \mathrm{FiO}_{2}<200$

\section{Cardiac complications}

- Acute myocardial infarction within 14 days after surgery: as determined on the basis of creatine phosphokinase $>30 \mathrm{ng} / \mathrm{mL}$ ( 5 times above normal), troponin I > $5 \mathrm{ng} / \mathrm{mL}$ within $72 \mathrm{~h}$ after surgery, the presence of new pathological $Q$ waves, or the medical record entry

- Arrhythmia requiring intervention or delaying hospital discharge

\section{Infectious complications}

- Sepsis: suspected infection associated with at least two of the following variables ${ }^{(18-20)}$ :

- Temperature $>38^{\circ} \mathrm{C}$ or $<36^{\circ} \mathrm{C}$

- Heart rate $>90$ bpm

- Respiratory rate $>20$ breaths/min

- Blood workup showing leukocytosis $(>12,000$ cells $/ \mu \mathrm{L})$, leukopenia $(<4,000$ cells $/ \mu \mathrm{L})$, or more than $10 \%$ of immature forms

- Signs of organ dysfunction, such as systolic blood pressure $<90 \mathrm{mmHg}$, mean arterial pressure $<70 \mathrm{mmHg}, \mathrm{PaO}_{2} / \mathrm{FiO}_{2}<300$, diuresis $<0.5 \mathrm{~mL} / \mathrm{kg} / \mathrm{h}$, creatinine elevation $>0.5 \mathrm{mg} / \mathrm{dL}$, international normalized ratio $>1.5$ or prothrombin time $>60 \mathrm{~s}$, platelets $<100,000 / \mu \mathrm{L}$, or plasma total bilirubin $>$ $4 \mathrm{mg} / \mathrm{dL}$

- Pleural empyema

- Surgical wound infection

\section{Renal and metabolic complications}

- Kidney injury: creatinine $>1.5 \mathrm{mg} / \mathrm{dL}$ or creatinine elevation $>0.5 \mathrm{mg} / \mathrm{dL}$ within $24 \mathrm{~h}$

\section{Hematological complications}

- Deep vein thrombosis (confirmed by Doppler)

\section{Neurological complications}

- Stroke

- Delirium

\section{Surgical complications}

- Need for blood transfusion

- Prolonged drainage (longer than 7 days)

- Prolonged air leaks (longer than 7 days)

- Inadvertent injury to intrathoracic structures

- Bronchial stump fistula

- Reoperation

\section{Other definitions}

Readmission within 60 days and 30-day mortality, regardless of their cause

All complications were recorded individually; however, the number of patients/cases with complications is what was used for analysis, given that various patients had more than one complication. 
In the present study, categorical variables are expressed as absolute numbers and proportions. All numerical variables were tested for normality of distribution with the use of graphical methods and the Shapiro-Wilk test. Variables with normal distribution are expressed as means and standard deviations; those with non-normal distribution are expressed as medians and interquartile ranges (25-75\%). To determine predictors of 30-day mortality and postoperative complications, we used logistic regression models. To determine which variables would be included in the model, we used the backward method, with those variables with $p>0.05$ being excluded. All study tests were performed with the IBM SPSS Statistics software package, version 20.0 (IBM Corporation, Armonk, NY, USA). Values of $p \leq 0.05$ were considered statistically significant.

\section{RESULTS}

Data on a total of 786 cases and described by 18 thoracic surgeons (mean number of resections per surgeon, 43.6) from 14 groups in various Brazilian states (São Paulo, Rio Grande do Sul, Rio de Janeiro, Ceará, Rio Grande do Norte, and Minas Gerais) and the Federal District of Brasília were compiled. Of those, 137 cases were excluded because of missing data that precluded analysis or because of inconsistencies, such as duplicate entries. Therefore, the study sample comprised 649 patients.

Study participant demographic data are detailed in Table 1. Most patients $(n=521 ; 89.8 \%$ ) had undergone surgery for neoplastic disease. Non-neoplastic diseases are listed at the food of Table 1. In 69 cases, no data were available on diagnosis leading to surgery. Among the patients with cancer, the diagnosis was adenocarcinoma, in 369 (70.7\%); squamous cell carcinoma, in $56(10.6 \%)$; carcinoid tumors, in $46(8.8 \%)$; large cell carcinoma, in $6(1.5 \%)$; small cell carcinoma, in 2 $(0.4 \%)$; secondary pulmonary neoplasia (metastases), in $29(5.4 \%)$; and other types of neoplasia, in 14 $(2.6 \%)$. In cases of primary pulmonary neoplasia, stage IA predominated, according to the clinical stage data for 425 patients and the pathological stage data for 483 patients. Neoplastic disease distribution by stage is detailed in Table 2 .

Table 3 summarizes the surgical results observed in our study sample. Table 4 lists the intraoperative and postoperative complications reported in the databases. Conversion to thoracotomy was necessary in 30 cases $(4.6 \%)$, and the reasons were hemorrhage, in 11 (37.9\%); technical difficulties or prolonged operative time, in 9 (31.1\%); and inadvertent bronchial injury, inadequate one-lung ventilation, and pleuropulmonary adhesions, in 3 cases each (10.3\%). The reason for

Table 1. Demographic data of the 649 patients included in the study.

\begin{tabular}{|c|c|}
\hline Variable & Result \\
\hline Age, years $(n=646)^{b}$ & $61.7 \pm 14.7(3-87)$ \\
\hline \multicolumn{2}{|l|}{ Gender $(N=649)$} \\
\hline Male & $295(45.5)$ \\
\hline Female & $354(54.5)$ \\
\hline \multicolumn{2}{|l|}{ Diagnosis $(n=580)$} \\
\hline Neoplasia & $521(89.8)$ \\
\hline Non-neoplasiac & $59(10.2)$ \\
\hline \multicolumn{2}{|l|}{ Smoking status $(n=648)$} \\
\hline Nonsmoker & $191(29.5)$ \\
\hline Smoker & $269(41.5)$ \\
\hline Former smoker & $188(29.0)$ \\
\hline \multicolumn{2}{|l|}{ Comorbidity } \\
\hline $\operatorname{COPD}(n=628)$ & $234(37.2)$ \\
\hline Coronary artery disease $(\mathrm{N}=649)$ & $70(10.8)$ \\
\hline Congestive heart failure $(N=649)$ & $22(3.4)$ \\
\hline Diabetes mellitus $(n=602)$ & $85(14.2)$ \\
\hline \multicolumn{2}{|l|}{ Type of surgery $(\mathrm{N}=649)$} \\
\hline Segmentectomy & $35(5.4)$ \\
\hline Lobectomy & $598(92.1)$ \\
\hline Bilobectomy & $9(1.4)$ \\
\hline Pneumonectomy & $7(1.1)$ \\
\hline \multicolumn{2}{|l|}{ Lobectomy $(n=598)$} \\
\hline Right upper & $168(28.1)$ \\
\hline Middle & $52(8.7)$ \\
\hline Right lower & $113(18.9)$ \\
\hline Left upper & $135(22.6)$ \\
\hline Left lower & $125(20.9)$ \\
\hline No data & $5(0.8)$ \\
\hline
\end{tabular}

avalues expressed as $\mathrm{n}(\%)$, except where otherwise indicated. 'Value expressed as mean \pm SD (minimummaximum). 'Suppurative disease $(n=37)$; lung malformation $(n=10)$; benign tumor $(n=6)$; bullous emphysema $(n=2)$; thrombosis of the middle lobe vein $(n=1)$; recurrent pneumothorax $(n=1)$; arteriovenous fistula $(n=$ $1)$; and cryptococcosis $(n=1)$. 
Table 2. Neoplastic disease stage. ${ }^{a}$

$\begin{array}{ccc}\text { Stage } & \text { Clinical }(\mathbf{n}=\mathbf{4 2 5}) & \text { Pathological }(\mathbf{n}=\mathbf{4 8 3}) \\ \text { IA } & 244(57.5) & 235(48.7) \\ \text { IB } & 90(21.2) & 122(25.2) \\ \text { IIA } & 34(8.0) & 56(11.6) \\ \text { IIB } & 33(7.7) & 34(7.0) \\ \text { IIIA } & 14(3.3) & 30(6.2) \\ \text { IIIB } & 1(0.2) & 0(0.0) \\ \text { IV } & 9(2.1) & 6(1.3)\end{array}$

avalues expressed as $n(\%)$.

Table 3. Surgical results.

\begin{tabular}{lc}
\multicolumn{1}{c}{ Variable } & Result \\
\hline Length of hospital stay $(\mathrm{n}=570)^{\mathrm{b}}$ & $4(3-6)$ \\
$\quad$ Hospital stay longer than 7 days & $103(18.1)$ \\
Length of ICU stay $(\mathrm{n}=606)^{\mathrm{b}}$ & $1(1-2)$ \\
Duration of drainage $(\mathrm{n}=647)$ & $3(2-4)$ \\
$\quad$ Drainage longer than 7 days & $53(8.2)$ \\
Conversion to thoracotomy $(\mathrm{N}=649)$ & $30(4.6)$ \\
Intraoperative complications $(\mathrm{N}=649)$ & $28(4.3)$ \\
Postoperative complications $(\mathrm{N}=649)$ & $124(19.1)$ \\
Reoperation ( $\mathrm{n}=495)$ & $26(5.2)$ \\
Readmission within 60 days $(\mathrm{n}=495)$ & $34(6.9)$ \\
30-day mortality $(\mathrm{n}=495)$ & $10(2.0)$ \\
\hline
\end{tabular}

aalues expressed as $n(\%)$, except where otherwise indicated. 'Values expressed as median (interquartile range).

conversion to thoracotomy was not informed in 1 case. There was no intraoperative mortality in our sample.

Table 5 shows predictors of postoperative complications and 30-day mortality. Advanced age, male gender, heart failure, and intraoperative accidents increased the likelihood of postoperative complications, whereas advanced age and diabetes mellitus contributed to the likelihood of 30-day mortality. In the mortality analysis, we conducted a sensitivity test by removing the variable intraoperative complications and found no significant change in the values for the other variables, proving that the model was stable and independent of that variable.

\section{DISCUSSION}

In this multicenter study, we found, after analyzing 649 cases, an intraoperative complication rate of $4.3 \%$. In 124 patients $(19.1 \%)$, there were postoperative complications, totaling 241 complications ( 55 patients had 2 or more complications). The 30 -day mortality rate was $2.0 \%$, and the median hospital stay was 4 days. Among the predictors analyzed in our sample, advanced age and diabetes mellitus were found to influence mortality. The postoperative complication rate was also influenced by advanced age, as well as by male gender, heart failure, and intraoperative accidents.

Females predominated in our sample, which is in agreement with information contained in databases in the USA ${ }^{(15-17)}$; however, according to information
Table 4. Morbidity and (intraoperative and postoperative) complications.

\begin{tabular}{|c|c|}
\hline Intraoperative complications ( $\mathrm{n}=28$ ) & n (\%) \\
\hline $\begin{array}{l}\text { Injury to a pulmonary artery and/or its } \\
\text { branches }\end{array}$ & $14(50.0)$ \\
\hline $\begin{array}{l}\text { Injury to a pulmonary vein and/or its } \\
\text { branches }\end{array}$ & $6(21.3)$ \\
\hline Bronchial injury & $4(14.3)$ \\
\hline Pulmonary parenchymal injury & $1(3.6)$ \\
\hline Arrhythmia & $1(3.6)$ \\
\hline Cardiopulmonary arrest & $1(3.6)$ \\
\hline No data & $1(3.6)$ \\
\hline \multicolumn{2}{|l|}{ Morbidity ( $n=649$ ) } \\
\hline Patients without complications & $525(80.9)$ \\
\hline Patients with complications & $124(19.1)$ \\
\hline Patients with 1 complication & $69(10.6)$ \\
\hline Patients with 2 complications & $24(3.7)$ \\
\hline Patients with 3 or more complications & $31(4.8)$ \\
\hline \multicolumn{2}{|l|}{ Postoperative complications } \\
\hline Pneumonia & $46(7.1)$ \\
\hline Prolonged air leaks (longer than 7 days) & $36(5.5)$ \\
\hline Atelectasis & $27(4.2)$ \\
\hline Arrhythmia & $20(3.1)$ \\
\hline Empyema & $17(2.6)$ \\
\hline Sepsis & $17(2.6)$ \\
\hline Respiratory failure & $16(2.5)$ \\
\hline Delirium & $16(2.5)$ \\
\hline Acute kidney injury & $14(2.1)$ \\
\hline ARDS & $12(1.8)$ \\
\hline Surgical wound infection & $7(1.1)$ \\
\hline Pulmonary thromboembolism & $4(0.6)$ \\
\hline Deep vein thrombosis & $2(0.3)$ \\
\hline Bronchial stump fistula & $2(0.3)$ \\
\hline Acute myocardial infarction & $1(0.1)$ \\
\hline Stroke & $1(0.1)$ \\
\hline No data & $3(0.4)$ \\
\hline
\end{tabular}

contained in the European Society of Thoracic Surgeons (ESTS) database, ${ }^{(14)}$ there is a predominance of males. The mean age in our sample was slightly lower in comparison with all the databases studied.(14-17) In our sample, the prevalence of heart failure and diabetes was higher than that reported in the Society of Thoracic Surgeons (STS) database ${ }^{(15)}$ and in the ESTS database, ${ }^{(14)}$ and the rates of coronary artery disease were higher than those reported in the ESTS database ${ }^{(14)}$ but lower than those reported in the three databases from the USA. ${ }^{(15-17)}$ These comparisons are detailed in Table 6. ${ }^{(18,21-23)}$

The postoperative complication rate found in our study was lower than those reported in the ESTS database and in the STS database (19.1\% vs. $29.1 \%$ and $26.23 \%$, respectively), ${ }^{(14,15)}$ which can in part be explained by the retrospective nature of the present study and by the possible loss of information or underreporting of complications, given that many of the patients included in the present study had undergone surgical treatment more than 5 years previously. Nevertheless, we found 
higher rates of pneumonia, atelectasis, empyema, sepsis, respiratory failure, delirium, acute kidney injury, ARDS, surgical wound infection, deep vein thrombosis, and pulmonary thromboembolism than did those studies. ${ }^{(14,15)}$ In contrast, the rates of prolonged air leaks, arrhythmia, acute myocardial infarction,

Table 5. Multivariate analysis.

\begin{tabular}{lcccc}
\multicolumn{1}{c}{ Postoperative complications } & OR & $\mathbf{p}$ & $\mathbf{9 5 \%} \mathbf{C I}$ & $\beta$ \\
\hline Age & 1.033 & 0.001 & $0.10-10.2$ & 0.032 \\
Female gender & 0.489 & 0.003 & $0.23-8.98$ & -0.715 \\
Congestive heart failure & 3.617 & 0.005 & $0.46-7.76$ & 1.286 \\
Intraoperative accidents & 2.685 & 0.02 & $0.42-5.41$ & 0.988 \\
$\quad$ 30-day mortality & & & & 0.085 \\
Age & 1.088 & 0.034 & $0.04-4.49$ & 1.439 \\
Diabetes mellitus & 4.218 & 0.032 & $0.67-4.60$ & \\
\hline
\end{tabular}

Table 6. Comparisons of demographic data, results, and postoperative complications among databases.

\begin{tabular}{|c|c|c|c|c|c|}
\hline \multirow[t]{2}{*}{ Variable } & \multicolumn{5}{|c|}{ Database } \\
\hline & $\begin{array}{l}\text { VATS Brazil } \\
(\mathrm{N}=649)\end{array}$ & $\begin{array}{c}\text { ESTS }^{(14)} \\
(\mathrm{N}=2,721)\end{array}$ & $\begin{array}{c}\text { STS }^{(15)} \\
(\mathbf{N}=1,281)\end{array}$ & $\begin{array}{c}\operatorname{SID}^{(16)} \\
(\mathrm{N}=2,427)\end{array}$ & $\begin{array}{l}\text { Premier }{ }^{(17)} \\
(\mathrm{N}=295)\end{array}$ \\
\hline \multicolumn{6}{|l|}{ Gender, \% } \\
\hline Male & 45.5 & 58.2 & 42.1 & 44 & 44.7 \\
\hline Female & 54.5 & 41.8 & 57.9 & 56 & 55.3 \\
\hline Age, years, mean $\pm S D$ & $61.7 \pm 14.7$ & $63.3 \pm 11.3$ & $65.1 \pm 12.1$ & 66.3 & 66.54 \\
\hline \multicolumn{6}{|l|}{ Smoking status, \% } \\
\hline Nonsmoker & 29.5 & - & 74.63 & - & - \\
\hline Smoker & 41.5 & - & 25.37 & - & - \\
\hline Former smoker & 29.0 & - & - & - & - \\
\hline \multicolumn{6}{|l|}{ Comorbidity, \% } \\
\hline COPD & 37.2 & - & - & 43 & 51.86 \\
\hline CAD & 10.8 & 8.4 & 14.6 & 17 & 8.14 \\
\hline $\mathrm{CHF}$ & 3.4 & 1.1 & 2.11 & 4 & 5.42 \\
\hline DM & 14.2 & 13.9 & 11.0 & 16 & 20.34 \\
\hline \multicolumn{6}{|l|}{ Lobectomy, \% } \\
\hline Right upper & 28.2 & 32.1 & - & - & - \\
\hline Middle & 8.7 & 9.2 & - & - & - \\
\hline Right lower & 19.5 & 17.4 & - & - & - \\
\hline Left upper & 22.7 & 21.9 & - & - & - \\
\hline Left lower & 20.9 & 17.4 & - & - & - \\
\hline 30-day mortality, \% & 2.0 & 1.0 & 0.94 & 1.1 & 2.7 \\
\hline Postoperative complications, \% & 19.1 & 29.1 & 26.23 & 43.6 & 9.47 \\
\hline \multicolumn{6}{|l|}{ Length of hospital stay } \\
\hline Median & 4 & 6 & 4 & 5 & 4 \\
\hline Mean \pm SD & $6.75 \pm 23.4$ & $7.8 \pm 5.8$ & - & - & $5.83 \pm 5.03$ \\
\hline Pneumonia, n (\%) & $46(7.1)$ & $163(6.0)$ & $38(2.97)$ & - & $29(9.83)$ \\
\hline Prolonged air leaks, n (\%) & $36(5.5)$ & $275(10.1)$ & $97(7.57)$ & - & $70(23.73)$ \\
\hline Atelectasis, n (\%) & $27(4.2)$ & $65(2.4)$ & $27(2.1)$ & - & $43(14.58)$ \\
\hline Arrhythmia, n (\%) & $20(3.1)$ & $116(4.3)$ & $93(7.26)$ & - & - \\
\hline Empyema, n (\%) & $17(2.6)$ & $13(0.5)$ & $1(0.08)$ & - & $2(0.68)$ \\
\hline Sepsis, n (\%) & $17(2.6)$ & - & $6(0.47)$ & - & - \\
\hline Respiratory failure, n (\%) & $16(2.5)$ & $27(1.0)$ & $24(1.88)$ & - & $22(7.46)$ \\
\hline Delirium, n (\%) & $16(2.5)$ & $34(1.2)$ & - & - & - \\
\hline AKI, n (\%) & $14(2.1)$ & $9(0.3)$ & - & - & - \\
\hline ARDS, n (\%) & $12(1.8)$ & $20(0.7)$ & $9(0.7)$ & - & - \\
\hline Surgical wound infection, $\mathrm{n}(\%)$ & $7(1.1)$ & $6(0.2)$ & $3(0.23)$ & - & $0(0.0)$ \\
\hline PTE, n (\%) & $4(0.6)$ & $11(0.4)$ & $3(0.23)$ & - & - \\
\hline DVT, n (\%) & $2(0.3)$ & - & $2(0.16)$ & - & - \\
\hline AMI, n (\%) & $1(0.1)$ & $5(0.2)$ & $1(0.08)$ & - & - \\
\hline Stroke, n (\%) & $1(0.1)$ & $17(0.6)$ & - & - & - \\
\hline
\end{tabular}

VATS: video-assisted thoracic surgery; ESTS: European Society of Thoracic Surgeons; STS: Society of Thoracic Surgeons; and SID: Seed Information Database. CAD: coronary artery disease; CHF: congestive heart failure; DM: diabetes mellitus; AKI: acute kidney injury; PTE: pulmonary thromboembolism; DVT: deep vein thrombosis; and AMI: acute myocardial infarction. 
and stroke found in our study were low, which in part can be explained by the lower incidence of COPD and chronic arterial disease in our population (Table 6).

The number of infectious complications-empyema, pneumonia, or sepsis-in our sample is of note. One of the likely explanations is the fact that more than $15 \%$ of the patients included in our study had diseases associated with lung infections, such as bronchiectasis or tuberculosis, which could predispose to such complications and are less common in studies conducted in the USA and in Europe. ${ }^{(24)}$ We were unable to statistically establish this correlation; however, the statistical power is low for this analysis. In any case, this is an indicator that should be paid attention to in the future.

In Brazil, there have been no studies describing complications of video-assisted thoracoscopic lobectomy; however, a study conducted at the Santa Casa Hospital Complex in Porto Alegre, located in the state of Rio Grande do Sul, Brazil, describes complications related to traditional lobectomy in lung donors. ${ }^{(25)}$ In that study, $31.25 \%$ of the patients had one or more complications, the most common being pleural effusion. (25) Another study conducted in the same state, also regarding lobectomy via thoracotomy, reported a complication rate of $44 \%$, in addition to an intraoperative mortality rate of $2.9 \%$. ${ }^{(26)}$ The mean age of those patients, 63.7 \pm 9.7 years, was similar to that found in our sample; however, most of those patients (83.9\%) had one or more comorbidities, and $90 \%$ had a history of smoking. The most common complication was air leaks. ${ }^{(26)} \mathrm{A}$ lower complication rate, $18.6 \%$, was documented in a study conducted by the State University at Campinas; however, in the study, there were other procedures that did not involve resection of lung parenchyma. (27)

Our study has limitations, and the most significant is its retrospective design. As previously mentioned, we may have underestimated the actual number of complications occurring in the cases studied. In addition, we cannot classify the severity of the complications observed, since the definition of which was determined a posteriori and the data in the medical records were very heterogeneous. The present study included cases on the learning curve of most participating surgeons (with up to 50 cases per surgeon) ${ }^{(28)}$; therefore, if, on one hand, less experience might lead to a greater number of complications, on the other, favorable cases are likely to have been selected. In addition, the participation of surgeons was voluntary, so it is possible that the surgeons participating in the study do not fully represent all thoracic surgery groups in Brazil. Furthermore, although the data were collected and organized by only one researcher, each surgeon was responsible for their database and there may therefore be heterogeneity in the data provided.

As shown in the present study, anatomic pulmonary resections by video-assisted thoracoscopy have been performed at several centers throughout Brazil. The results of these surgeries, which represent the results for the learning curve of the several centers and therefore constitute the critical mass regarding video-assisted resections in our country, are consistent with the results observed in large international databases. Since the technique has been safely and successfully implemented in the participating institutions, strategies should be developed to increase access to this minimally invasive alternative. Advanced age and heart failure, which are preoperative predictors of complications, should be taken into account when considering this type of surgery.

\section{ACKNOWLEDGMENTS}

We would like to thank the thoracic surgeons who participated indirectly in this study by providing us with cases that were computed as part of institutional databases: Pedro Henrique Xavier Nabuco de Araujo, Letícia Leone Lauricella, Alberto Jorge Monteiro Dela Veja, and Benoit Jacques Bibas (University of São Paulo); José Jesus Camargo, José Carlos Felicetti, and Fabíola Perin (Santa Casa Hospital Complex in Porto Alegre); and Daniel Bonomi (Mário Penna Institute).

\section{REFERENCES}

1. Taioli E, Lee DS, Lesser M, Flores R. Long-term survival in videoassisted thoracoscopic lobectomy vs open lobectomy in lung-cance patients: a meta-analysis. Eur J Cardiothorac Surg. 2013;44(4):591-7. http://dx.doi.org/10.1093/ejcts/ezt051

2. Cao C, Manganas $C$, Ang SC, Yan TD. A meta-analysis of unmatched and matched patients comparing video-assisted thoracoscopic lobectomy and conventional open lobectomy. Ann Cardiothorac Surg. 2012;1(1):16-23. http://dx.doi.org/ 10.3978/j.issn.2225319X.2012.04.18

3. Swanson SJ, Herndon JE 2nd, D'Amico TA, Demmy TL, McKenna RJ Jr, Green MR, et al. DJ. Video-assisted thoracic surgery lobectomy: report of CALGB 39802-a prospective, multi-institution feasibility study. J Clin Oncol. 2007;25(31):4993-7. http://dx.doi.org/10.1200/ JCO.2007.12.6649

4. Flores RM, Park BJ, Dycoco J, Aronova A, Hirth Y, Rizk NP et al. Lobectomy by video-assisted thoracic surgery (VATS versus thoracotomy for lung cancer. J Thorac Cardiovasc Surg 2009;138(1):11-8. http://dx.doi.org/10.1016/j.jtcvs.2009.03.030

5. Lewis RJ, Caccavale RJ, Sisler GE, Mackenzie JW. Video-assisted thoracic surgical resection of malignant lung tumors. J Thorac
Cardiovasc Surg. 1992;104(6):1679-85; discussion 1685-7

6. Chin CS, Swanson SJ. Video-assisted thoracic surgery lobectomy: centers of excellence or excellence of centers? Thorac Surg Clin. 2008;18(3):263-8. http://dx.doi.org/10.1016/j.thorsurg.2008.04.001

7. Brunelli A, Falcoz PE, D'Amico T, Hansen H, Lim E, Massard G, et al. European guidelines on structure and qualification of general thoracic surgery. Eur J Cardiothorac Surg. 2014;45(5):779-86. http://dx.doi. org/10.1093/ejcts/ezu016

8. Cooke DT, Wisner DH. Who performs complex noncardiac thoracic surgery in United States academic medical centers? Ann Thorac Surg. 2012;94(4):1060-4. http://dx.doi.org/10.1016/j. athoracsur.2012.04.018

9. Terra RM, Waisberg DR, Almeida JL, Devido MS, Pêgo-Fernandes $\mathrm{PM}$, Jatene FB. Does videothoracoscopy improve clinical outcomes when implemented as part of a pleural empyema treatment algorithm? Clinics (Sao Paulo). 2012;67(6):557-64. http://dx.doi. org/10.6061/clinics/2012(06)03

10. Cirino LM, Milanez de Campos JR, Fernandez A, Samano MN Fernandez PP, Filomeno LT, et al. Diagnosis and treatment of mediastinal tumors by thoracoscopy. Chest. 2000;117(6):1787-92. 
http://dx.doi.org/10.1378/chest.117.6.1787

11. McKenna RJ Jr, Houck W, Fuller CB. Video-assisted thoracic surgery lobectomy: experience with 1,100 cases. Ann Thorac Surg 2006;81(2):421-5; discussion 425-6. http://dx.doi.org/10.1016/j. athoracsur.2005.07.078

12. Paul S, Altorki NK, Sheng S, Lee PC, Harpole DH, Onaitis MW, Stiles BM, Port JL, D'Amico TA. Thoracoscopic lobectomy is associated with lower morbidity than open lobectomy: a propensitymatched analysis from the STS database. J Thorac Cardiovasc Surg. 2010;139(2):366-78. http://dx.doi.org/10.1016/j.jtcvs.2009.08.026

13. Rocco G, Internullo E, Cassivi SD, Van Raemdonck D, Ferguson MK The variability of practice in minimally invasive thoracic surgery for pulmonary resections. Thorac Surg Clin. 2008;18(3):235-47. http:// dx.doi.org/10.1016/j.thorsurg.2008.06.002

14. Falcoz PE, Puyraveau M, Thomas PA, Decaluwe $H$, Hürtgen $M$, Petersen $\mathrm{RH}$, et al. Video-assisted thoracoscopic surgery versus open lobectomy for primary non-small-cell lung cancer: a propensitymatched analysis of outcome from the European Society of Thoracic Surgeon database. Eur J Cardiothorac Surg. 2016;49(2):602-9. http:// dx.doi.org/10.1093/ejcts/ezv154

15. Paul S, Altorki NK, Sheng S, Lee PC, Harpole DH, Onaitis MW, et al. Thoracoscopic lobectomy is associated with lower morbidity than open lobectomy: a propensity-matched analysis from the STS database. J Thorac Cardiovasc Surg. 2010;139(2):366-78. http:// dx.doi.org/10.1016/j.jtcvs.2009.08.026

16. Kent M, Wang T, Whyte R, Curran T, Flores R, Gangadharan S. Open, video-assisted thoracic surgery, and robotic lobectomy: review of a national database. Ann Thorac Surg. 2014;97(1):236-42; discussion 242-4. http://dx.doi.org/10.1016/j.athoracsur.2013.07.117

17. Swanson SJ, Miller DL, McKenna RJ Jr, Howington J, Marshall MB Yoo AC, et al. Comparing robot-assisted thoracic surgical lobectomy with conventional video-assisted thoracic surgical lobectomy and wedge resection: results from a multihospital database (Premier) J Thorac Cardiovasc Surg. 2014;147(3):929-37. http://dx.doi. org/10.1016/j.jtcvs.2013.09.046

18. Lever A, Mackenzie I. Sepsis: definition, epidemiology, and diagnosis. BMJ. 2007:335(7625):879-83. http://dx.doi.org/10.1136/ bmj.39346.495880.AE

19. Kaukonen KM, Bailey M, Pilcher D, Cooper DJ, Bellomo R. Systemic inflammatory response syndrome criteria in defining severe sepsis N Engl J Med. 2015;372(17):1629-38. http://dx.doi.org/10.1056/

\section{NEJMoa1415236}

20. Bone RC, Balk RA, Cerra FB, Dellinger RP, Fein AM, Knaus WA et al. Definitions for sepsis and organ failure and guidelines for the use of innovative therapies in sepsis. The ACCP/SCCM Consensus Conference Committee. American College of Chest Physicians/ Society of Critical Care Medicine. Chest. 1992;101(6):1644-55. http:// dx.doi.org/10.1378/chest.101.6.1644

21. Boffa DJ, Gangadharan S, Kent M, Kerendi F, Onaitis M, Verrie E, et al. Self-perceived video-assisted thoracic surgery lobectomy proficiency by recent graduates of North American thoracic residencies. Interact Cardiovasc Thorac Surg. 2012;14(6):797-800. http://dx.doi.org/10.1093/icvts/ivr098

22. Piwkowski C, Gabryel P, Gałęcki B, Roszak M, Dyszkiewicz WI. High costs as a slow down factor of thoracoscopic lobectomy development in Poland - an institutional experience. Wideochir Inne Tech Maloinwazyjne. 2013;8(4):334-41. http://dx.doi.org/10.5114/ wiitm.2011.35633

23. Swanson SJ, Meyers BF, Gunnarsson CL, Moore M, Howington JA, Maddaus MA, et al. Video-assisted thoracoscopic lobectomy is less costly and morbid than open lobectomy: a retrospective multiinstitutional databaseanalysis. Ann Thorac Surg. 2012;93(4):102732. http://dx.doi.org/10.1016/j.athoracsur.2011.06.007

24. World Health Organization [homepage on the Internet]. Geneva: WHO [cited 2015 Dec 1]. Tuberculosis country profiles. Available from: http://who.int/tb/country/data/profiles/en/

25. Camargo SM, Camargo Jde J, Schio SM, Sánchez LB, Felicetti JC Moreira Jda S, et al. Complications related to lobectomy in living lobar lung transplant donors. J Bras Pneumol. 2008;34(5):256-63.

26. Sánchez PG, Vendrame GS, Madke GR, Pilla ES, Camargo Jde J, Andrade CF, et al. Lobectomy for treating bronchial carcinoma: analysis of comorbidities and their impact on postoperative morbidity and mortality. J Bras Pneumol. 2006;32(6):495-504. http://dx.doi. org/10.1590/S1806-37132006000600005

27. Saad IA, De Capitani EM, Toro IF, Zambon L. Clinical variables of preoperative risk in thoracic surgery. Sao Paulo Med J. $\quad 2003 ; 121(3): 107-10$. http://dx.doi.org/10.1590/S151631802003000300004

28. Yan TD, Cao C, D'Amico TA, Demmy TL, He J, Hansen H, Swanson SJ, et al. Video-assisted thoracoscopic surgery lobectomy at 20 years: a consensus statement. Eur J Cardiothoracic Surg. 2014;45(4):633-9. http://dx.doi.org/10.1093/ejcts/ezt463 